\title{
Integrated effect of plant growth regulators with boron sources on some biological parameters of sugar beet
}

\author{
Marwa A. Qotob ${ }^{\text {a }}$, Mostafa A. Nasef ${ }^{\text {a }}$, Heba K. A. Elhakim ${ }^{\text {b }}$, Olfat G. Shaker ${ }^{\mathrm{c}}$, Nader R. Habashy ${ }^{\mathrm{a}}$, Ismail A. \\ Abdelhamid $^{\mathrm{d}}$ \\ ${ }^{a}$ Soils, Water and Environment Research Institute, Agriculture Research Center, Giza, Egypt \\ ${ }^{b}$ Biochemistry department, Faculty of Science, Cairo University, Giza 12613, Egypt. \\ ${ }^{c}$ Department of Biochemistry, Faculty of Medicine, Cairo University, Egypt. \\ ${ }^{d}$ Department of Chemistry, Faculty of Science, Cairo University, Giza12613, Egypt.
}

\begin{abstract}
Any improvement in agricultural systems that results higher production aimed to reduce negative environmental impacts and enhance sustainability plant growth regulators (PGRs) such as gibberellin have similar physiological and biological effects to those of plant hormones, and therefore used widely in agriculture to minimize unwanted shoot growth without lowering plant productivity.

An experimental field was conducted at Giza Experimental Station Egypt, on sugar beet plants (Beta vulgaris L. var. Sara poly) with some plant growth regulators (gibberellin and proline) foliar application at three rates of zero (control), 100 and $200 \mathrm{mg} \mathrm{l}^{-1}$ and boron sources (Boric acid and B-NPs) with 75\% of macronutrients from full dose.

The main target of this study to evaluate another plant growth regulator source like proline which is safer than gibberellin for maximizing sugar beet biological parameters to reduce the gap between sugar consumption and production in presence of boron sources.

Data showed that the foliar applications of gibberellin $\left(\mathrm{GA}_{3}\right)$ at rate $100 \mathrm{mg} \mathrm{l}^{-1}$ and proline at $200 \mathrm{mg} \mathrm{l}^{-1}$ were found to be the more effective without significant differences for plant growth, productivity and quality may be due to increased $\mathrm{N}$ use efficiency, especially at sub-optimal macro nutrient fertilizers. Regard to boron sources, B-NPs had positive effect on all biological parameters under study due to sugar transport, cell membrane synthesis, nitrogen fixation, respiration, carbohydrate metabolisms, root growth, functional characteristics and development.
\end{abstract}

Keywards:

Proline; $\mathrm{GA}_{3}$; Boric acid; B-NPs; Macro-nutrient fertilizers; Sucrose quality; sugar beet; Betaine; Choline

\section{Introduction}

Sugar beet (the raw material of the beet sugar factory) composition is important to both the sugar beet farmer and the factory. Sugar (sucrose) and non-sugar (non-sucrose) content determine the quality of the sugar beet where, high sugar and low non-sugar content is desirable. So it is important to evaluate the chemical quality of sugar beet roots in order to evaluate their quality for sugar production. Root yield and technical quality of sugar beet are strongly influenced by weather conditions. The technical quality of sugar beet is essential for economical sugar manufacturing (Asadi, 2006). The wide majority of beets are grown by independent farmers, who are contracted by the factories directly. The industrial demand for sugar beets is increasing, which provides a higher price, incentivizing many farmers to plant more beets. FAS (Foreign Agricultural services) Cairo is increasing sugar beet area harvested in MY 2019/20 to 250,000 ha. Post is revising down last year's harvested area to 225,000 hectares instead of 230,000. With the decreased area harvested, post also revised down MY 2018/19 production to 9.5 MMT, six percent below earlier estimates. Macronutrients fertilization is among the vital factors affecting growth, quality and productivity of sugar beet, thus application the suitable rates of nitrogen, phosphorus and potassium one of the favorable factors for increasing sugar beet productivity and quality. The proper fertilization reference can be given only based on the soil fertility. It must be determining optimum nitrogen rate, which produce the maximum root, sugar yields and quality parameters (Seadh, 2012).

Plant growth regulators are hormones that widely used in agriculture to increase plant growth and reproduction. The commonly used class of plant growth regulators includes plant growth hormones such as cytokinin, and gibberellic acid (Fukao and Bailey-Serres, 2008).

Gibberellins involved in a number of cellular processes that regulate seed germination and growth of aerial plant parts, including floral induction and fruit development (Spaepen, S.; Vanderleyden, J. and 
Okon, 2009). The effect of spray of gibberellic acid $\left(\mathrm{GA}_{3}\right)$ at very low concentrations could be exploited beneficially as its natural occurrence in plants in minute quantities is known to control their development. It is an established phytohormone used commercially for improving the productivity and quality of a number of crop plants (King and Evans, 2003).

Proline is the most widely distributed metabolite that accumulates under stress conditions (Delauney and Verma, 1993) the significance of this accumulation in osmotic adjustment in plants is still debated and varies from species to species (Hoai et al., 2003). The crystallization of sugar in the industrial processing of beet root in sugar refineries may be jeopardized by accumulation of compounds, such as proline and glucose, because they lead to the formation of coloured components that reduce the quality of beet roots (Monreal et al., 2007).

Boron is one of the important micronutrient among essential elements for plant growth, and plays a significant role in the physiological and biochemical processes within plants (Tariq and Mott, 2006). Boron plays a key role in higher plants by facilitating the short-and long-distance transport of sugar via the formation of borate-sugar complexes. In addition, boron may be of importance for maintaining the structural integrity of plasma plant cells membranes. This function is likely related to stabilization of cell membranes by boron association with some membrane constituents (Brown et al., 2002).

Nanotechnology to precisely detects and delivers the correct quantity of nutrients and pesticides and increases the bioavailability (Goudar et al., 2018) which promote productivity while ensuring environmental safety and higher use efficiency. Nano boron has many merits like quick and easy uptake by plants. It has lower tendency to leach via soil and appear its impact for shorter times. It improves solubility and dispersion of insoluble nutrients in soil, reduces soil fixation.

The main target of this study using some plant growth regulators i.e. gibberellin and proline to increase sugar beet productivity and its biological parameters without hazard effect on human beings and environment in presence of boron sources (Boric acid and Nano boron) with controlled use of macro-nutrient fertilizers .

\section{Materials and methods}

A field experiment was conducted on a clay texture soil at El Giza Agricultural Research Station, Egypt (located between $30^{\circ} \mathrm{N}, 31^{\circ}: 28 \mathrm{E}$ at an altitude 19 meters above sea level) and cultivated with sugar beet (Beta vulgaris var. Sara poly) during winter season of 2018. The current study aimed to identify the direct beneficial effects on applying some plant growth regulators as gibberellin and proline at different rates $\left(100,200 \mathrm{mg} \mathrm{l}^{-1}\right)$ with two boron sources (boric acid and nano boron, B-NPs) at recommended dose for sugar beet $\left(0.48 \mathrm{Kg} \mathrm{B} \mathrm{acre}^{-1}\right)$ at full dose and $75 \%$ from full dose of macronutrient fertilizers. The nano boron (B-NPs) analysis of X-ray pattern in (Fig. 1).

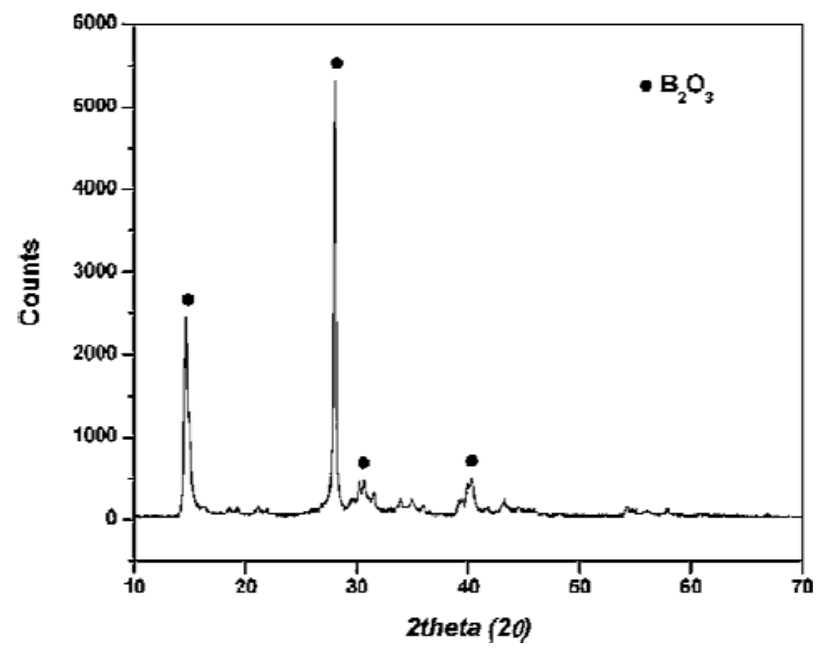

Fig. 1. X-ray pattern of the $\mathrm{B}_{2} \mathrm{O}_{3} \mathrm{NPs}(1-45 \mathrm{~nm})$

The experiment was laid-out in split- split plot design with three replicates as follows: 
a. The main plots were $75 \%$ from full dose. Calcium super phosphate $\left(15.5 \% \mathrm{P}_{2} \mathrm{O}_{5}\right)$ was added at rate $112.5 \mathrm{P}_{2} \mathrm{O}_{5} \mathrm{Kg}_{\text {acre }}{ }^{-1}$ during the soil preparation. Nitrogen was applied at rate of $56.5 \mathrm{Kg} \mathrm{N}$ acre ${ }^{-1}$ as urea $(46.5 \% \mathrm{~N})$ in three equal doses after 21,45 and 60 days from planting. Potassium sulphate $(50 \%$ $\mathrm{K}_{2} \mathrm{O}$ ) at rate of $37.5 \mathrm{Kg} \mathrm{K}_{2} \mathrm{O}$ acre $^{-1}$ was added in two equal doses after 30 and 50 days from planting. Foliar applications of both plant growth regulators and boron were applied after 45 and 60 days from sowing. All cultural practices for growing sugar beet were done as recommended.

b. The sub plots were plant growth regulators i.e. $\mathrm{GA}_{3}$ (Natural Enterprise Co.) and proline (Alfa Aesar Co.) at three rates as a foliar application (Zero, 100 and $200 \mathrm{mg} \mathrm{l}^{-1}$ ).

c. The sub - sub plots were applied foliar with two boron sources boric acid (Aldrich Co.) and B-NPs (Yara Fertiliser Co.) at the recommended dose for sugar beet $\left(0.48 \mathrm{Kg} \mathrm{B}\right.$ acre $\left.^{-1}\right)$

An agricultural soil sample (0-30 cm depth) was used for the study. It was air-dried, ground and sieved with a $2 \mathrm{~mm}$ sieve. Some of its properties were estimated according to (Page et al., 1982). The total $\mathrm{N}$ was determined by distillation in a Macro-Kjeldahl (Gerhardt model VAP $30 \mathrm{~S}$ ). Total P was estimated colorimetrically using stannous chloride mixture and measured by UV/Vis spectrophotometer (JENWAY model $6705 \mathrm{UV} / \mathrm{Vis}$ ), while $\mathrm{K}^{+}$and $\mathrm{Na}^{+}$concentrations were measured by flame photometer (JENWAY model PFP7). The concentrations of $\mathrm{Ca}^{+2}, \mathrm{Mg}^{+2}, \mathrm{Fe}, \mathrm{Mn}, \mathrm{Zn}, \mathrm{Cu}$ and B were measured by ICP-AAS spectrophotometer (Agilent Technologies model 8800) (Jackson, 1959), (Cottenie et al., 1982), Tabulated in (Table 1).

Chemical analyses of sugar beet plants were carried out on the samples to determine boron by ICP (Inductively coupled plasma) spectrometry (model, Ultima 2 JY Plasma) (Jackson, 1959), (Cottenie et al., 1982), total sugar were determined in sugar beet roots calorimetrically with the picric acid method as described by (Thomas and Dutcher, 1924), betaine was determined by (Focht et al., 1956), choline was determined according to (Gimesi and Szász, 1974), proline was investigated by (Carillo and Gibon, 2011) by the absorbance of the extract measured Spectrophotometer using by JENWAY 6705 UV/Vis., gibberellin was determined using gas spectroscopy model Trace $1310 \mathrm{GC}$ as described by (Moritz and Monteiro, 1994), total soluble solids was determined by (Mariani et al., 2014) using refractometer (model J57HA), determination of $\alpha$ - Amino nitrogen by (Shtanheev et al., 1998), purity was measured by (Guyot, 1967).

Table 1

Chemical and physical characteristics of initial soil under investigation.

\begin{tabular}{|c|c|c|c|}
\hline Soil characteristics & Value & Soil characteristics & Value \\
\hline Particle size distribution\%: & & Soluble cations (soil paste, $\mathrm{mmol}_{\mathrm{c}} \mathrm{l}^{-1}$ ): & \\
\hline Sand & 26.2 & $\mathrm{Ca}^{+2}$ & 2.35 \\
\hline Silt & 29.3 & $\mathrm{Mg}^{+2}$ & 1.20 \\
\hline Clay & 44.5 & $\mathrm{Na}^{+}$ & 6.85 \\
\hline Soil textural class & Clay* & $\mathrm{K}^{+}$ & 5.13 \\
\hline Soil chemical properties: & & Soluble anions (soil paste, $\operatorname{mmol}_{\mathrm{c}} \mathrm{l}^{-1}$ ): & \\
\hline $\mathrm{pH}(1: 2.5$ soil water suspension $)$ & 8.95 & $\mathrm{CO}_{3}^{-2}$ & 0.00 \\
\hline $\mathrm{CaCO}_{3} \%$ & 4.82 & $\mathrm{HCO}^{-3}$ & 3.15 \\
\hline Organic matter $\%$ & 1.53 & $\mathrm{Cl}^{-}$ & 6.40 \\
\hline $\mathrm{EC}_{\mathrm{e}}\left(\mathrm{dS} \mathrm{m} \mathrm{m}^{-1}\right.$, soil past $)$ & 1.69 & $\mathrm{SO}_{4}^{-2}$ & 5.95 \\
\hline Soil physical properties: & & Available macro- and micronutrients $\mathrm{mg} \mathrm{kg}^{-1}$ & \\
\hline Bulk density, $\mathrm{g} \mathrm{cm}^{-3}$ & 1.20 & $\mathrm{~N}$ & 46.34 \\
\hline Sodium adsorption ratio (SAR) & 5.15 & $\mathrm{P}$ & 18.56 \\
\hline Exchangeable sodium (ESP) & 4.50 & $\mathrm{~K}$ & 349.1 \\
\hline Saturation (SP) & 70.3 & $\mathrm{Fe}$ & 41.2 \\
\hline $\mathrm{CEC}^{* *} \mathrm{cmol}_{\mathrm{c}} \mathrm{kg}^{-1}$ & 53.2 & $\mathrm{Mn}$ & 26.1 \\
\hline Moisture content $\%$ : & & $\mathrm{Zn}$ & 2.43 \\
\hline Field capacity & 27 & $\mathrm{~B}$ & 1.13 \\
\hline Wilting point & 16 & & \\
\hline Available water & 11 & & \\
\hline
\end{tabular}


Data statistically analyzed by the analysis of variance (ANOVA) was carried out to determine the statistical significance using the least significant difference at level at 0.05 (Gomez and Gomez, 1984).

\section{Results and discussion}

The aim of this study to reduce the consumption of mineral fertilizers through using plant growth regulators (gibberellin or proline) at the same time evaluate possibility replace the gibberellin by proline which showed its harmful effect on animal and human cells according to (Wang et al., 2011) who stated that the present study clearly demonstrated that PGRs including gibberellin and cytokinin may cause acute toxicity and teratogenic effect in both neonate and embryo cells.

\subsection{Pigment content in sugar beet}

The obtained data in Table 2 revealed that the foliar application of plant growth regulators (gibberellin and proline) increased the pigment content i.e. chlorophyll-a; chlorophyll-b and carotenoids where the mean values at rate $100 \mathrm{mg} \mathrm{l}^{-1}$ gibberellin and $200 \mathrm{mg}^{-1}$ proline were 6.15 and

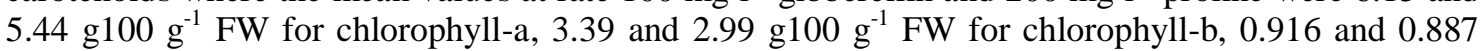
$\mathrm{g} 100 \mathrm{~g}^{-1} \mathrm{FW}$, respectively. Exogenous application of gibberellins (GAs) has shown enhanced activities of carbonic anhydrase, nitrate reductase (Afroz, S., Mohammad, F., Hayat, S., Siddiqui, 2005), $\mathrm{CO}_{2}$ fixation, stomatal conductance (Bishnoi and Krishnamoorthy, 1991) and ribulose-1,5biphosphate carboxylase/oxygenase (Yuan and $\mathrm{Xu}, 2001$ ). GAs alters membrane permeability to ions (Gilroy, S. and Jones, 1992) and improves translocation potential to the sink (Peretó and Beltrán, 1987). The physiological and biochemical modes of action of $\mathrm{GA}_{3}$ is likely responsible for increasing shoot dry biomass plants. Generally, lower concentrations of plant growth regulators are biochemically more active with higher concentrations becoming toxic (Kulkarni et al., 2013). Proline, a multifunctional amino acid, besides acting as an excellent osmolyte is also known for stabilizing subcellular structures such as proteins and cell membranes, scavenging free radicals, balancing cellular homeostasis and signaling events and buffering redox potential under stress conditions (Hayat et al., 2012). It could be reflecting on maintaining the nutrient status in roots.

\section{Table 2}

Integrated effect of plant growth regulators and mineral fertilizer rates with different boron sources on sugar beet pigments.

\begin{tabular}{|c|c|c|c|c|c|c|c|c|}
\hline \multirow{2}{*}{ Boron sources } & \multirow[b]{2}{*}{ Control } & \multicolumn{4}{|c|}{ Gibberellin $\left(\mathrm{mg} \mathrm{l}^{-1}\right)$} & \multicolumn{3}{|c|}{ Proline $\left(\mathrm{mg} \mathrm{l}^{-1}\right)$} \\
\hline & & & 100 & 200 & Mean & 100 & 200 & Mean \\
\hline \multicolumn{9}{|c|}{ Chlorophyll-a (g 100g ${ }^{-1}$ FW) } \\
\hline Control & 3.14 & & 5.59 & 4.99 & 4.57 & 4.10 & 5.12 & 4.12 \\
\hline Boric acid & 3.23 & & 6.18 & 5.49 & 4.96 & 4.83 & 5.25 & 4.44 \\
\hline Nano B & 3.46 & & 6.67 & 5.70 & 5.28 & 4.90 & 5.94 & 4.77 \\
\hline Mean & 3.28 & & 6.15 & 5.39 & 4.94 & 4.61 & 5.44 & 4.44 \\
\hline \multicolumn{9}{|c|}{ Chlorophyll-b $\left(\right.$ g 100g $^{-1}$ FW) } \\
\hline Control & 1.33 & & 2.71 & 2.68 & 2.24 & 2.45 & 2.70 & 2.16 \\
\hline Boric acid & 1.59 & & 3.65 & 3.22 & 2.82 & 2.60 & 2.92 & 2.37 \\
\hline Nano B & 1.72 & & 3.80 & 3.50 & 3.01 & 2.73 & 3.35 & 2.60 \\
\hline Mean & 1.55 & & 3.39 & 3.13 & 2.69 & 2.59 & 2.99 & 2.38 \\
\hline \multicolumn{9}{|c|}{ Carotenoids $\left({\left.\mathrm{g} 100 \mathrm{~g}^{-1} \mathrm{FW}\right)}\right.$} \\
\hline Control & 0.673 & & 0.831 & 0.728 & 0.744 & 0.731 & 0.802 & 0.735 \\
\hline Boric acid & 0.685 & & 0.937 & 0.746 & 0.789 & 0.769 & 0.892 & 0.782 \\
\hline Nano B & 0.708 & & 0.981 & 0.771 & 0.820 & 0.824 & 0.978 & 0.837 \\
\hline Mean & 0.689 & & 0.916 & 0.748 & 0.784 & 0.775 & 0.881 & 0.783 \\
\hline \multicolumn{9}{|c|}{ L.S.D. at 0.05} \\
\hline & B & $\mathrm{G}$ & $\mathrm{R}$ & $B \times G$ & $\mathrm{~B} \times \mathrm{R}$ & & & B x G x R \\
\hline Chlorophyll-a & 0.61 & 1.01 & 0.55 & 0.57 & 0.56 & & & 0.50 \\
\hline Chlorophyll-b & 0.37 & 0.85 & 0.45 & 0.51 & 0.11 & & & 0.35 \\
\hline Carotenoids & 0.02 & 0.03 & 0.10 & 0.09 & 0.04 & & & 0.02 \\
\hline
\end{tabular}


This report is in conformity with the increased nitrate content of roots by exogenous application of proline (Alyemeni et al., 2016). exogenous application of proline mitigated the decreased plant growth caused by stress is through increasing antioxidant system, relieving oxidative damage, improving the synthesis of compatible solutes, and accelerating proline accumulation, which reflected on enhancing photosynthesis (Anjum et al., 2011). Also, the chlorophyll molecules are the membrane bound structures whose stability depends highly on the integrity of the membrane structure which is possibly maintained by proline as it acts as a membrane stabilizer (Ashraf, M. and Foolad, 2007).

Regard to boron sources, data showed that foliar application of nano boron on sugar beet plants was more respond than boric acid where the chlorophyll-a, chlorophyll-b and carotenoids contents

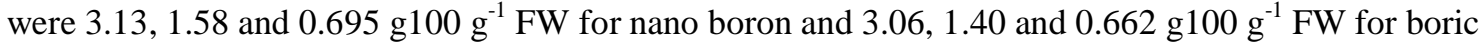
acid, respectively. This result was in agreement with (Hassan et al., 2013) who reported that application of boron increase net photosynthetic rate which may be attributed to the increase in chlorophylls content of leaves. Furthermore, application of boron increased the activity of catalase and glutathione reductase, which act as antioxidants thus saving the electron transport mechanism of plant from getting oxidized by free radicals like superoxide radicals, singlet oxygen radicals (Wojcik et al., 2008). Also, (Davarpanah et al., 2016) indicated that the foliar application of nano-B fertilizers in plant increased the leaf concentrations of both microelements, reflecting the improvements in nutrient status.

In general, it could be noted that the interaction between foliar application of plant growth regulators accompanied with boron sources used give more respond than plant growth regulators or boron sources sole and the more effective treatment were $100 \mathrm{mg} \mathrm{l}^{-1}$ gibberellin and $200 \mathrm{mg} \mathrm{l}^{-1}$ proline with nano boron without any significant differences.

\subsection{Residual content of applied plant growth regulators and boron sources used in sugar beet roots}

Data showed in Table 3 that the foliar application of plant growth regulators (Gibberellin or Proline) at two rates 100 and $200 \mathrm{mg} \mathrm{kg}^{-1}$ on sugar beet roots residual content increased by application of gibberellin. The obtained data was in agreement with (Kim et al., 2008) who reported that $\mathrm{GA}_{3}$ applications significantly increased endogenous $\mathrm{GA}_{3}$ content in the plants. On contrast, proline application did not affect the residual content of gibberellin when applied at both rate compared to control treatment. According to (Osman, 2015) exogenous application of proline might be not only accelerated the translocation process of amino acids from source to sink, but also suppressed the conversion process from amino acids to proteins.

Also, data showed that the residual content of proline and boron increased by application rates of gibberellin, this may be due to that the gibberellic acid may stimulated plant on building protein and the optimum transform of nutrients although the unavailability of moisture in the plant to a certain level (Al-Shaheen and Soh, 2016). Regard to the application of proline at 100 and $200 \mathrm{mg} \mathrm{kg}^{-1}$ proline and boron content were increased by increasing proline concentration. According to (Kahlaoui et al., 2014) the exogenous application of proline leads to a significant increase in the proline accumulation of both organs (leaves and roots) in plant.

Further study showed that amino acids such as proline have a chelating effect on micronutrients when applied together; the absorption and transportation of micronutrients inside the plant is easier, this effect is due to the chelating action, the effect of cell membrane permeability and low molecular weight (Westwood, 1993).

Regard to the foliar application of boron on plants of sugar beet (Beta vulgaris L.) in the form of boric acid or B-NPs, the obtained data showed that the mean values of proline content were 2.45 , 2.17, 2.62, and $2.35 \mu \mathrm{mol} \mathrm{g}{ }^{-1} \mathrm{FW}$, gibberellin content 13.07, 13.02, 13.15 and $13.09 \mathrm{mg} \mathrm{kg}^{-1}$ and boron content 49.82, 45.98, 52.45 and $49.75 \mathrm{mg} \mathrm{kg}^{-1}$, respectively. According to (Nilanjan, 2013) stated that compared to the conventional boric acid or Borax fertilizers, all of which are on the macro scale (on the order of micrometers) (macro boric acid"), the boron nanofertilizers of embodiments 
217

herein (on the order of nanometers) shows a sharp increase in crop yield (increased biomass, potato tuber yield, and plant weight) and crop quality (less reducing sugar and increased starch content).

Table 3

Residual content of plant growth regulators applied with different boron sources on sugar beet roots.

\begin{tabular}{|c|c|c|c|c|c|c|c|c|}
\hline \multirow{2}{*}{ Boron sources (B) } & \multirow[b]{2}{*}{ Control } & \multicolumn{4}{|c|}{ Gibberellin $\left(\mathrm{mg} \mathrm{l}^{-1}\right)$} & \multicolumn{3}{|c|}{ Proline $\left(\mathrm{mg} \mathrm{l}^{-1}\right)$} \\
\hline & & & 100 & 200 & Mean & 100 & 200 & Mean \\
\hline \multicolumn{9}{|c|}{ Proline $\left(\mu \mathrm{mol} \mathrm{\textrm {g } ^ { - 1 }} \mathrm{FW}\right)$} \\
\hline Control & 2.16 & & 2.39 & 2.16 & 2.28 & 2.25 & 2.45 & 2.33 \\
\hline Boric acid & 2.29 & & 3.06 & 2.74 & 2.75 & 2.69 & 2.78 & 2.64 \\
\hline Nano B & 2.41 & & 3.11 & 2.85 & 2.86 & 2.84 & 3.01 & 2.82 \\
\hline Mean & 2.45 & & 2.85 & 2.58 & 2.63 & 2.59 & 2.75 & 2.60 \\
\hline \multicolumn{9}{|c|}{ Gibberellin (mg kg $\left.{ }^{-1}\right)$} \\
\hline Control & 13.05 & & 15.68 & 14.70 & 14.48 & 13.46 & 13.61 & 13.37 \\
\hline Boric acid & 13.07 & & 16.25 & 15.54 & 14.95 & 13.62 & 13.89 & 13.53 \\
\hline Nano B & 13.15 & & 16.75 & 15.80 & 15.23 & 13.80 & 14.15 & 13.70 \\
\hline Mean & 13.09 & & 16.23 & 15.35 & 14.89 & 13.63 & 13.88 & 13.53 \\
\hline \multicolumn{9}{|c|}{ Boron (mg kg ${ }^{-1}$ ) } \\
\hline Control & 46.21 & & 65.82 & 60.45 & 56.97 & 61.09 & 67.38 & 57.71 \\
\hline Boric acid & 49.82 & & 78.64 & 66.12 & 63.58 & 65.62 & 70.53 & 60.71 \\
\hline Nano B & 52.45 & & 84.35 & 72.30 & 68.80 & 73.86 & 78.81 & 67.47 \\
\hline Mean & 49.49 & & 76.27 & 66.29 & 63.12 & 66.86 & 72.24 & 61.96 \\
\hline \multicolumn{9}{|c|}{ L.S.D. 0.05} \\
\hline & B & G & $\mathrm{R}$ & $B \times G$ & & & $G \times R$ & B x G x R \\
\hline Proline & 0.08 & 0.15 & 0.11 & 0.10 & & & 0.12 & 0.05 \\
\hline Gibberellin & 0.15 & 1.20 & 0.50 & 0.21 & & & 0.20 & 1.40 \\
\hline Boron & 2.01 & 3.10 & 4.71 & 4.55 & & & 4.85 & 1.25 \\
\hline
\end{tabular}

Finally, the interaction analysis for $75 \%$ NPK from the recommended dose accompanied with foliar application of gibberellin at rate $100 \mathrm{mg} \mathrm{l}^{-1}$ and nano boron (NPs) was the most effective treatment than the same interaction with boric acid.

\subsection{Sugar extraction and quality parameters}

Data obtained in (Table 4) revealed that the foliar application of plant growth regulator as a gibberellin at rate $100 \mathrm{mg} \mathrm{l}^{-1}$ give the highest values for sucrose, purity and total soluble solids whereby increase the rate of gibberellin at rate of $200 \mathrm{mg} \mathrm{l}^{-1}$ the was observed that decreased in all pervious parameters. In contrast, the results showed that the foliar application of proline gave higher response at $200 \mathrm{mg} \mathrm{l}^{-1}$ than $100 \mathrm{mg} \mathrm{l}^{-1}$ as application rates where, proline, a multifunctional amino acid, besides acting as an excellent osmolyte is also known for stabilizing subcellular structures such as proteins and cell membranes, scavenging free radicals, balancing cellular homeostasis and signaling events and buffering redox potential under stress conditions (Hayat et al., 2012).

Also, (Asil et al., 2011) who indicated drenching with gibberellin increased the floral stalk height as compared to the control. It may be attributed to the effect of gibberellin in stimulating and accelerating cell division, increasing cell elongation and enlargement, or both (Hartmann and Kester, 1963).

Regard to data in (Table 4) the foliar application of boric acid and B-NPs as a boron sources on sugar beet plants observed that nano boron source was more effective than boric acid for sucrose, purity, $\alpha$ - amino nitrogen and total soluble solids with values $(16.48,16.32$ and $16.69,16.41 \%)$, (80.47, 80.25 and 80.62, 80.31\%), (1.15, 1.37 and 1.32, 1.21\%) and $\left(19.4,18.4\right.$ and 19.8, 18.7 Brix $^{\square}$ ), respectively. These results were in agreement with (Naderi et al., 2011) who dedicated that application of nanofertilizers instead of common fertilizers, where nutrients are provided to plants 
gradually and in a controlled manner. Meanwhile, the nanotechnology increases the application efficiency of fertilizers, decreases pollution and risks of chemical fertilization.

Table 4

Integrated effect of plant growth regulators and macro-nutrients fertilizer rates with different boron sources on Sugar content and quality.

\begin{tabular}{|c|c|c|c|c|c|c|c|c|}
\hline \multirow{2}{*}{ Boron sources (B) } & \multirow[b]{2}{*}{ Control } & & \multicolumn{3}{|c|}{ Gibberellin $\left(\mathrm{mg} \mathrm{l}^{-1}\right)$} & \multicolumn{3}{|c|}{ Proline $\left(\mathrm{mg} \mathrm{l}^{-1}\right)$} \\
\hline & & & 100 & 200 & Mean & 100 & 200 & Mean \\
\hline \multicolumn{9}{|c|}{ Sucrose (\%) } \\
\hline Control & 16.09 & & 17.65 & 16.81 & 16,82 & 16.95 & 17.48 & 16.84 \\
\hline Boric acid & 16.48 & & 18.30 & 16.90 & 17.23 & 17.10 & 17.70 & 17.09 \\
\hline Nano boron & 16.69 & & 18.90 & 17.60 & 17.79 & 17.84 & 18.65 & 17.73 \\
\hline Mean & 16.42 & & 18.28 & 17.10 & 17.24 & 17.30 & 17.94 & 17.22 \\
\hline \multicolumn{9}{|c|}{ Purity (\%) } \\
\hline Control & 80.42 & & 82.80 & 81.89 & 81.60 & 82.07 & 82.43 & 81.54 \\
\hline Boric acid & 80.47 & & 83.57 & 82.21 & 82.01 & 82.71 & 82.75 & 81.90 \\
\hline Nano boron & 80.62 & & 84.51 & 82.85 & 82.56 & 82.80 & 83.99 & 82.47 \\
\hline Mean & 80.50 & & 83.63 & 82.32 & 82.01 & 82.53 & 83.06 & 81.97 \\
\hline \multicolumn{9}{|c|}{$\alpha$ - Amino nitrogen (\%) } \\
\hline Control & 1.24 & & 1.12 & 1.27 & 1.14 & 1.23 & 1.12 & 1.13 \\
\hline Boric acid & 1.15 & & 1.17 & 1.17 & 1.24 & 1.08 & 1.22 & 1.22 \\
\hline Nano boron & 1.32 & & 1.02 & 1.19 & 1.14 & 1.28 & 1.26 & 1.25 \\
\hline Mean & 1.24 & & 1.10 & 1.21 & 1.17 & 1.20 & 1.20 & 1.20 \\
\hline \multicolumn{9}{|c|}{ Total Soluble Solids (Brix ${ }^{\square}$ ) } \\
\hline Control & 18.2 & & 21.9 & 20.8 & 20.3 & 21.4 & 21.9 & 20.4 \\
\hline Boric acid & 19.4 & & 23.8 & 22.1 & 21.4 & 22.6 & 23.3 & 21.4 \\
\hline Nano boron & 19.8 & & 25.3 & 23.5 & 22.5 & 23.4 & 24.2 & 21.9 \\
\hline Mean & 19.1 & & 23.7 & 22.1 & 21.5 & 22.5 & 23.1 & 21.4 \\
\hline \multicolumn{9}{|c|}{ L.S.D. 0.05} \\
\hline & $\mathrm{B}$ & $\mathrm{G}$ & $\mathrm{R}$ & $B \times G$ & $\mathrm{~B} \times \mathrm{R}$ & & $\mathrm{G} \times \mathrm{R}$ & B x G x R \\
\hline Sucrose & 0.11 & 0.65 & 0.30 & 0.49 & 0.51 & & 0.60 & 0.05 \\
\hline Purity & 0.08 & 0.70 & 0.25 & 0.25 & 0.80 & & 0.42 & 0.10 \\
\hline aAmino $\mathrm{N}$ & 0.10 & 0.18 & 0.09 & 0.11 & 0.21 & & 0.09 & 0.08 \\
\hline TSS & 0.25 & 1.15 & 0.35 & 0.40 & 0.75 & & 0.58 & 0.15 \\
\hline
\end{tabular}

$\mathbf{B}=$ Boron sources; $\mathbf{G}=$ Plant growth regulator sources and $\mathbf{R}=$ Rate of Plant growth regulator

Finally, the interaction analysis for $75 \%$ NPK from the recommended dose accompanied with foliar application of gibberellin at rate $100 \mathrm{mg} \mathrm{l}^{-1}$ and proline at rate $200 \mathrm{mg} \mathrm{l}^{-1}$ with nano boron was the most effective treatment than the same interaction with boric acid.

\subsection{Bio-chemical components of sugar beet}

The represented data in Table 5 showed that the foliar application of gibberellin at $100 \mathrm{mg} \mathrm{l}^{-1}$ was the most effective treatment followed by proline at $200 \mathrm{mg} \mathrm{l}^{-1}$ as in betaine content 0.172 and $0.171 \mathrm{~g}$

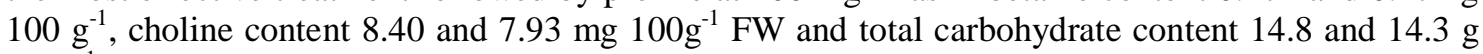
$100 \mathrm{~g}^{-1}$ ). These results in harmony with (El-Sherbeny and Da Silva, 2013) who reported that proline proved to be successful agents in improving growth and yield characters of beet plants, especially at $100 \mathrm{mg} \cdot \mathrm{L}^{-1}$ and $200 \mathrm{mg} \cdot \mathrm{L}^{-1}$ also, $\mathrm{GA}_{3}$ increases the chlorophyll concentrations in leaves by increasing the numbers and sizes of chloroplasts and enhances the ultra-structural morphogenesis of plastids (Richard N. A., 1996). In general, photosynthetic efficiency increases along with the chlorophyll concentration. Thus, exogenous $\mathrm{GA}_{3}$ indirectly causes the increase in chlorophyll (Ashraf et al., 2002) that resulted in the accumulation of more dry mass (Khan, 1996). High concentration of endogenous $\mathrm{GA}_{3}$ by increasing the gibberellin concentration treatment (Wang et al., 2015). In addition, $\mathrm{GA}_{3}$ caused the increase in the endogenous Indole acetic acid contents (Reid and Davies, 1992). The previous studies have illustrated that the exogenous application of proline mitigated the decreased plant growth caused by stress is through increasing antioxidant system, relieving oxidative damage, improving the synthesis of compatible solutes, and accelerating proline accumulation, which reflected on enhancing photosynthesis (Szabados and Savouré, 2010); (Anjum et al., 2011). Also, Sun Physiologically, a major function of GAs in higher plants can be generalized as stimulating organ growth through enhancement of cell elongation and, in some cases, cell division. In addition, GAs promotes certain developmental switches, such as between seed dormancy and germination, juvenile and adult growth phases, and vegetative and reproductive development. 
Table 5

Integrated effect of plant growth regulators and macro-nutrient fertilizer rates with different boron sources on biochemical contents

\begin{tabular}{|c|c|c|c|c|c|c|c|c|}
\hline \multirow{2}{*}{ Boron sources (B) } & \multirow[b]{2}{*}{ Control } & \multicolumn{4}{|c|}{ Gibberellin ( $\left.\mathrm{mg} \mathrm{l}^{-1}\right)$} & \multicolumn{3}{|c|}{ Proline $\left(\mathrm{mg} \mathrm{l}^{-1}\right)$} \\
\hline & & & 100 & 200 & Mean & 100 & 200 & Mean \\
\hline \multicolumn{9}{|c|}{ 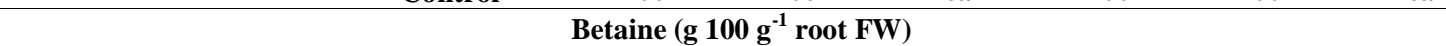 } \\
\hline Control & 0.162 & & 0.172 & 0.160 & 0.162 & 0.160 & 0.171 & 0.161 \\
\hline Boric acid & 0.168 & & 0.194 & 0.166 & 0.174 & 0.174 & 0.180 & 0.172 \\
\hline Nano boron & 0.173 & & 0.208 & 0.172 & 0.185 & 0.187 & 0.198 & 0.187 \\
\hline Mean & 0.168 & & 0.191 & 0.166 & 0.174 & 0.174 & 0.183 & 0.173 \\
\hline \multicolumn{9}{|c|}{ Choline (mg $100 \mathrm{~g}^{-1}$ root $\mathrm{FW}$ ) } \\
\hline Control & 7.45 & & 8.40 & 7.75 & 7.81 & 7.78 & 7.93 & 7.72 \\
\hline Boric acid & 7.51 & & 8.68 & 7.91 & 7.95 & 7.81 & 8.15 & 7.74 \\
\hline Nano boron & 7.58 & & 8.82 & 7.90 & 8.10 & 7.95 & 8.32 & 7.84 \\
\hline Mean & 7.51 & & 8.63 & 7.98 & 7.92 & 7.85 & 8.14 & 7.80 \\
\hline \multicolumn{9}{|c|}{ Total Carbohydrate $\left(\mathrm{g}^{100 \mathrm{~g}^{-1}}\right)$} \\
\hline Control & 13.1 & & 14.8 & 14.0 & 13.9 & 13.5 & 14.3 & 13.6 \\
\hline Boric acid & 13.7 & & 15.6 & 14.7 & 14.4 & 13.9 & 14.8 & 13.8 \\
\hline Nano boron & 13.9 & & 15.9 & 15.0 & 14.9 & 14.1 & 15.5 & 14.2 \\
\hline Mean & 13.6 & & 15.4 & 14.6 & 14.5 & 13.8 & 14.9 & 14.0 \\
\hline \multicolumn{9}{|c|}{ L.SD. 0.05} \\
\hline & B & $\mathrm{G}$ & $\mathrm{R}$ & $B \times G$ & $B \times R$ & & & $B \times G \times R$ \\
\hline Betaine & 0.001 & 0.005 & 0.01 & 0.002 & 0.01 & & & 0.001 \\
\hline Choline & 0.05 & 0.30 & 0.50 & 0.09 & 0.10 & & & 0.20 \\
\hline Total Carb. & 0.10 & 1.00 & 0.75 & 0.25 & 0.11 & & & 0.90 \\
\hline
\end{tabular}

Table 5 showed the foliar application of nano boron give higher results for betaine, choline and total carbohydrate than boric acid foliar application this may due to (Nilanjan, 2013) who stated that, one benefit of the boron nanofertilizer described in embodiments may be extremely low cost and high efficiency. Some embodiments described herein provide a highly effective means of nano-fertilization by administration of boric acid nanoparticles to plants. Nano scale boric acid released from the surface of metal nanoparticles of embodiments herein can be a highly efficient boron fertilizer. Other benefits of the boron coated metal nanoparticles described herein include increased boron content in plants resulting in increased chlorophyll content, number of leaves, total biomass, total yield, and lowered soluble and reducing sugars.

Finally, the interaction between the foliar application of gibberellin at $100 \mathrm{mg} \mathrm{l}^{-1}$ and proline at 200 $\mathrm{mg}^{-1}$ with nano boron with $75 \%$ of recommended dose give the highest response for most parameter under study of sugar beet plant these results was in agreement with (Seadh and El-Metwally, 2015) who reported that adding of plant growth regulators with addition mineral fertilizers with $80 \%$ of recommended dose in order to maintain high productivity and quality of plant at the same time reduce production costs and environmental pollution under the environmental condition in Egypt.

\section{Conclusion}

From previously data obtained could be concluded that the using of plant growth regulators as a proline or gibberellin reduced the consumption of mineral fertilizers and possibility of replacing the gibberellin by proline.

The application of nanotechnology in agriculture as using nano boron (B-NPs) increased the application efficiency, decreased pollution and risk of fertilizers used and increased plant quality. 


\section{Reference}

Afroz, S., Mohammad, F., Hayat, S., Siddiqui, M.H., 2005. Exogenous Application of Gibberellic Acid Counteracts the Ill Effect of Sodium Chloride in Mustard. Turkish J. Biol. 29, 233-236.

Al-Shaheen, M.R., Soh, A., 2016. Effect of proline and Gibberellic Acid on the qualities and qualitative of Corn (Zea maize L.) under the influence of different levels of the water stress. Int. J. Sci. Res. Publ. 6, 752-756.

Alyemeni, M.N., Hayat, Q., Hayat, S., Faizan, M., Faraz, A., 2016. Exogenous proline application enhances the efficiency of nitrogen fixation and assimilation in chickpea plants exposed to cadmium. An Int. Journal, Legum. Res. 39, 221-227. https://doi.org/10.18805/lr.v0iOF.9291

Anjum, S.A., Xie, X.Y., Wang, L.C., Saleem, M.F., Man, C., Lei, W., 2011. Morphological, physiological and biochemical responses of plants to drought stress. African J. Agric. Res. 6, 2026-2032. https://doi.org/10.5897/AJAR10.027

Asadi, M., 2006. Beet-Sugar Handbook, John Wiley \& Sons. John Wiley \& Sons.

Ashraf, M. and Foolad, M.R., 2007. Roles of glycine betaine and proline in improving plant abiotic stress resistance. Environ. Exp. Bot. 59, 206-216. https://doi.org/10.1016/j.envexpbot.2005.12.006

Ashraf, M., Karim, F., Rasul, E., 2002. Interactive effects of gibberellic acid (GA 3) and salt stress on growth, ion accumulation and photosynthetic capacity of two spring wheat (Triticum aestivum L.) cultivars differing in salt tolerance. Plant Growth Regul. 36, 49-59. https://doi.org/10.1023/A:1014780630479

Asil, M.H., Roein, Z., Abbasi, J., 2011. Response of tuberose (Polianthes tuberose L.) to gibberellic acid and benzyladenine. Hortic. Environ. Biotechnol. 52, 46-51. https://doi.org/10.1007/s13580011-0073-0

Bishnoi, N.R., Krishnamoorthy, H.N., 1991. Effect of waterlogging and gibberellic acid on leaf gas exchange in peanut (Arachis hypogaea L.). J. Plant Physiol. 139, 503-505. https://doi.org/10.1016/S0176-1617(11)80502-X

Brown, P.H., Bellaloui, N., Wimmer, M.A., Bassil, E.S., Ruiz, J., Hu, H., Römheld, V., 2002. Boron in plant biology. Plant Biol. https://doi.org/10.1055/s-2002-25740

Carillo, P., Gibon, Y., 2011. Protocol: extraction and determination of proline. PrometheusWiki 1-5.

Cottenie, A., Velghe, G., Verloo, M., Kiekens, L., 1982. Biological and analytical aspects of soil pollution., Lab. Of Analytical Agro. State Univ. of Calif. Division of Agric. Sci.

Davarpanah, S., Tehranifar, A., Davarynejad, G., Abadía, J., Khorasani, R., 2016. Effects of foliar applications of zinc and boron nano-fertilizers on pomegranate (Punica granatum cv. Ardestani) fruit yield and quality. Sci. Hortic. (Amsterdam). 210, 57-64. https://doi.org/10.1016/j.scienta.2016.07.003

Delauney, A.J., Verma, D.P.S., 1993. Proline biosynthesis and osmoregulation in plants. The plant journal. 4, 215-223. https://doi.org/10.1046/j.1365-313X.1993.04020215.x

El-Sherbeny, M.R., Da Silva, J.A.T., 2013. Foliar treatment with proline and tyrosine affect the growth and yield of beetroot and some pigments in beetroot leaves. Hortic. Res. 21, 95-99. https://doi.org/10.2478/johr-2013-0027

Focht, R.L., Schmidt, F.H., Dowling, B.B., 1956. Sugar Beet Processing, Colorimetric Determination of Betaine in Glutamate Process End Liquor. J. Agric. Food Chem. 4, 546-548. https://doi.org/10.1021/jf60064a007

Fukao, T., Bailey-Serres, J., 2008. Ethylene-a key regulator of submergence responses in rice. Plant Sci. 175, 43-51. https://doi.org/10.1016/j.plantsci.2007.12.002

Gilroy, S. and Jones, R.L., 1992. Gibberellic acid and abscisic acid coordinately regulate cytoplasmic calcium and secretory activity in barley aleurone protoplasts. Proc. Natl. Acad. Sci. U. S. A. 89, 3591-3595. https://doi.org/10.1073/pnas.89.8.3591

Gimesi, O., Szász, G., 1974. Determination of choline and trimethylamine in seeds and premixes. Period. Polytech. Chem. Eng. 18, 203-210.

Gomez, K.A., Gomez, A.A., 1984. Statistical Procedures for Agricultural Research., John Wiley \& Sons, Inc. New York 641. 
Goudar, K.M., Geetha, K.N., Lingaraju, N.N., Shankar, A.G., Raddy, R., 2018. Response of sunflower (Helianthus annuus L.) to nano boron nitride fertilization. Int. J. Chem. Stud. 6, 2624 2630.

Guyot, H.M., 1967. Process for treating sugar producing plants to effect improved saccharose yield. Pat. Trademark Off. 3,307,932.

Hartmann, H.T., Kester, D.E., 1963. Plant propagation: principles and practice." Soil Science 95, no. 1 (1963): 89. Soil Sci. 95, 89.

Hassan, G.A., Ahmad, T.B., Mohi-ud-din, R.A., 2013. An ethnobotanical study in Budgam district of Kashmir valley: an attempt to explore and document traditional knowledge of the area. , 4, 201204. Int. Res. J. Pharmacy. 4, 201-204.

Hayat, S., Hayat, Q., Alyemeni, M.N., Wani, A.S., Pichtel, J., Ahmad, A., 2012. Role of proline under changing environments: a review. Plant Signal. Behav. https://doi.org/10.4161/psb.21949

Hoai, N.T.T., Shim, I.S., Kobayashi, K., Kenji, U., 2003. Accumulation of some nitrogen compounds in response to salt stress and their relationships with salt tolerance in rice (Oryza sativa L.) seedlings. Plant Growth Regul. 41, 159-164. https://doi.org/10.1023/A:1027305522741

Jackson, M.L., 1959. Soil Chemical Analysis. J. Agric. Food Chem. 7, 138.

Kahlaoui, B., Hachicha, M., Rejeb, S., Rejeb, M.N., Hanchi, B., Misle, E., 2014. Response of two tomato cultivars to field-applied proline under irrigation with saline water: Growth, chlorophyll fluorescence and nutritional aspects. Photosynthetica 52, 421-429. https://doi.org/10.1007/s11099-014-0053-6

Khan, N.A., 1996. Effect of gibberellic acid on carbonic anhydrase, photosynthesis, growth and yield of mustard. Biol. Plant. 38, 145-147. https://doi.org/10.1007/BF02879650

Kim, S.G., Lee, A., Yoon, H.K., Park, C.M., 2008. A membrane-bound NAC transcription factor NTL8 regulates gibberellic acid-mediated salt signaling in Arabidopsis seed germination. Plant J. 55, 77-88. https://doi.org/10.1111/j.1365-313X.2008.03493.x

King, R. W. and Evans, L.T., 2003. Gibberellins and flowering of grasses and cereals $\square$ : Prizing Open the Lid of the "Florigen" Black Box. Annu. Rev. Plant Biol. 54, 307-328. https://doi.org/10.1146/annurev.arplant.54.031902.135029

Kulkarni, M. G.; Stirk, W. A.; Southway, C.; Papenfus, H. B.; Swart, P. A.; Lux, A.; Vaculík, M.; Martinka, M. and van Staden, J., 2013. PLANT GROWTH REGULATORS ENHANCE GOLD UPTAKE IN BRASSICA JUNCEA. Int. J. Phytoremediation 15, 117-126. https://doi.org/10.1080/15226514.2012.683207

Mariani, N., Da Costa, R., De Lima, K., Nardini, V., Cunha Júnior, L., Teixeira, G., 2014. Predicting soluble solid content in intact jaboticaba [Myrciaria jaboticaba (Vell.) O. Berg] fruit using nearinfrared spectroscopy and chemometrics. Food Chem. 159, 458-462. https://doi.org/10.1016/j.foodchem.2014.03.066

Monreal, J.A., Jimenez, E.T., Remesal, E., Morillo-Velarde, R., García-Mauriño, S., Echevarría, C., 2007. Proline content of sugar beet storage roots: Response to water deficit and nitrogen fertilization at field conditions. Environ. Exp. Bot. 60, 257-267. https://doi.org/10.1016/j.envexpbot.2006.11.002

Moritz, T., Monteiro, A.M., 1994. Analysis of endogenous gibberellins and gibberellin metabolites from Dalbergia dolichopetala by gas chromatography-mass spectrometry and high-performance liquid chromatography - mass spectrometry. Planta 193, 1-8. https: // doi .org /10.1007 /BF 00191599

Naderi, M., Danesh Shahraki, A.A., Naderi, R., 2011. Application of nanotechnology in the optimization of formulation of chemical fertilizers. Iran. J. Nanotechnol. 12, 16-23.

Nilanjan, D.E.B., 2013. Plant nutrient coated nanoparticles and methods for their preparation and use. WO 2013/121244 Al.

Osman, H.S., 2015. Enhancing antioxidant-yield relationship of pea plant under drought at different growth stages by exogenously applied glycine betaine and proline. Ann. Agric. Sci. 60, 389402. https://doi.org/10.1016/j.aoas.2015.10.004

Page, A.L., Miller, R.H., Keeney, D.R., 1982. Methods of soil analysis. Part 2. Chemical and microbiological properties, in: American Society of Agronomy, Soil Science Society of America. pp. 149-223. 
Peretó, J.G., Beltrán, J.P., 1987. Hormone directed sucrose transport during fruit set induced by gibberellins in Pisum sativum. Physiol. Plant. 69, 356-360. https://doi.org/10.1111/j.13993054.1987.tb04300.x

Reid, J.B., Davies, P.J., 1992. The genetics and physiology of gibberellin sensitivity mutants in peas., in: In Progress in Plant Growth Regulation. Springer Science \& Business Media, Dordrecht., pp. 214-225. https://doi.org/10.1007/978-94-011-2458-4_24

Richard N. A., 1996. Plant Growth Substances: Principles and Applications., in: Springer Science and Business Media. Springer Science \& Business Media, p. 332.

Seadh, S.E., 2012. Maximizing sugar beet yields with decreasing mineral fertilization pollution. Int. J. Agric. Sci. 4, 293-298.

Seadh, S.E., El-Metwally, M.A., 2015. Influence of antioxidants on wheat productivity, quality and seed-borne fungi management under NPK fertilization Levels. Asian J. Crop Sci. 7, 87-112. https://doi.org/10.3923/ajcs.2015.87.112

Shtanheev, V.O., Chernyavs'ka, L.I., Petrenko, H.O., Zayets', V.A., 1998. The method for determining the alpha-amino nitrogen content in [sugar] beet. FAO (Food Agric. Organ. 3).

Spaepen, S.; Vanderleyden, J. and Okon, Y., 2009. Chapter 7 Plant Growth-Promoting Actions of Rhizobacteria. Adv. Bot. Res. https://doi.org/10.1016/S0065-2296(09)51007-5

Szabados, L., Savouré, A., 2010. Proline: a multifunctional amino acid. Trends plant Sci. https://doi.org/10.1016/j.tplants.2009.11.009

Tariq, M. and Mott, C.J.B., 2006. Effect of boron supply on the uptake of micronutrients by Radish (Raphanus Sativus 1.). J. Agric. Biol. Sci. 1, 1-8.

Thomas, W., Dutcher, R.A., 1924. The colorimetric determination of carbohydrates in plants by the picric acid reduction method I. The estimation of reducing sugars and sucrose. J. Am. Chem. Soc. 46, 1662-1669. https://doi.org/10.1021/ja01672a015

Twarakavi, N. K. C., Šimůnek, J. and Schaap, M.G., 2010. Can texture-based classification optimally classify soils with respect to soil hydraulics?. Water Resour. Res. 46, 1-11. https://doi.org/10.1029/2009WR007939

Wang, L., Liu, J., Li, X., Shi, J., Hu, J., Cui, R., Zhang, Z. L., Pang, D.W., Chen, Y., 2011. Growth propagation of yeast in linear arrays of microfluidic chambers over many generations. Biomicrofluidics 5, 1-9. https://doi.org/10.1063/1.3668243

Wang, J., Cang, J., Liu, L., Zeng, Y., Wang, X., Xu, C., Zhang, D., 2015. Effects of Exogenous GA3 on Wheat Cold Tolerance. Agric. Sci. Technol. 17, 921-934.

Wojcik, V. A.; Frankie, G. W.; Thorp, R. W. and Hernandez, J.L., 2008. Seasonality in Bees and Their Floral Resource Plants at a Constructed Urban Bee Habitat in Berkeley, California. J. Kansas Entomol. Soc. https://doi.org/10.2307/25086414

Yuan, L., Xu, D., 2001. Stimulation effect of gibberellic acid short-term treatment on leaf photosynthesis related to the increase in Rubisco content in broad bean and soybean. Photosynth. Res. 68, 39-47. https://doi.org/10.1023/A:1011894912421 
bioRxiv preprint doi: https://doi.org/10.1101/839068; this version posted November 11,2019. The copyright holder for this preprint (which was not certified by peer review) is the author/funder, who has granted bioRxiv a license to display the preprint in perpetuity. It is made available under aCC-BY-NC-ND 4.0 International license.

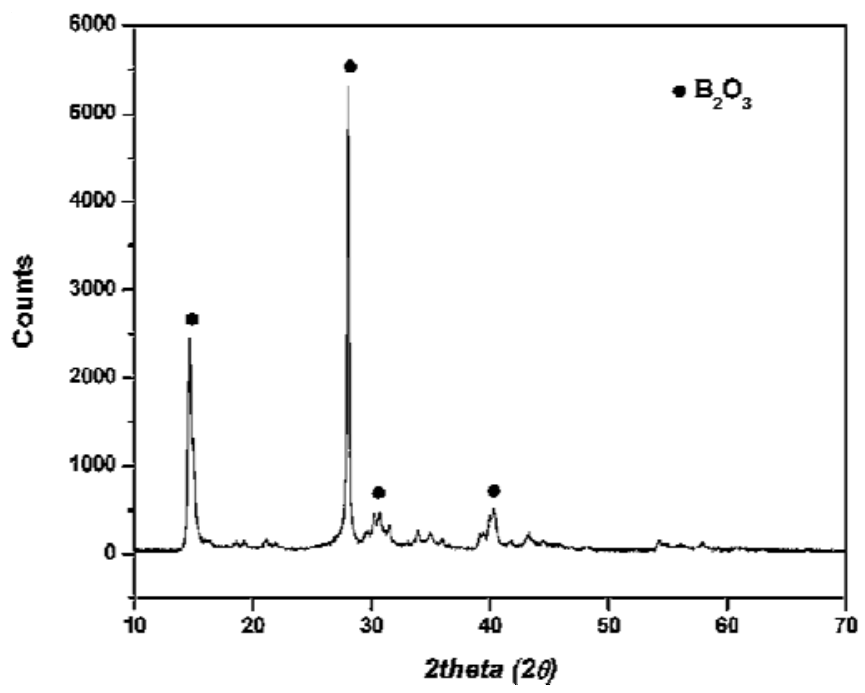

Fig. 1. X-ray pattern of the $\mathrm{B}_{2} \mathrm{O}_{3} \mathrm{NPs}(1-45 \mathrm{~nm})$ 